\title{
SKPP BAWASLU SEBAGAI SARANA PENDIDIKAN POLITIK DALAM UPAYA MENINGKATKAN PARTISIPASI POLITIK WARGA NEGARA
}

\author{
Nia Sofiyatul Millah \& Dinie Anggraenie Dewi \\ Universitas Islam Nusantara \& Universitas Pendidikan Indonesia \\ niasofiya31@gmail.com
}

\begin{abstract}
Abstrak
Partisipasi masyarakat dalam pemilu di Indonesia selalu menurun dari pemilu pertama hingga sekarang. Dengan adanya peranan aktif dari Bawaslu, sebagai lembaga pemantau pemilu serta masyarakat dalam mengawasi pemilu, diharapkan dapat memberikan kesadaran bagi para pelaku politik dan seluruh yang terlibat dalam Pemilu yang pada akhirnya akan melahirkan suatu pemilu yang demokratis. Dengan adanya partisipasi masyarakat dalam pengawasan tahapan penyelenggaraan pemilu maka diharapkan akan dapat menghasilkan pemilu yang demokratis baik dari prosesnya maupun hasilnya. SKPP adalah sebuah sarana Pendidikan yang disediakan oleh Badan Pengawas Pemilu (BAWASLU) untuk memfasilitasi masyarakat umum agar dapat terlibat dalam mengawasi penyelenggaraan pemilu atau pilkada. SKPP dibuat untuk mewadahi partisipasi masyarakat dalam pemilu. Kader-kader lulusan SKPP diharapkan menjadi kepanjangan tangan Bawaslu untuk meningkatkan partisipasi politik masyarakat terhadap penyelenggaraan pemilu/pilkada.
\end{abstract}

Kata Kunci: SKPP Bawaslu, Pengawas Partisipatif, Pemilu

\begin{abstract}
Abstrack
Public participation in elections in Indonesia has always decreased from the first election to the present. With the active role of Bawaslu, as an election monitoring institution and also the community in supervising the election, it is hoped that it can provide awareness for political actors and all those involved in the election which will eventually give birth to a democratic election. With the participation of the community in supervising the stages of organizing the election, it is hoped that it will be able to produce democratic elections both from the process and the results. SKPP is an educational facility provided by the Election Supervisory Body (BAWASLU) to facilitate the general public to be involved in supervising the implementation of elections or local elections. SKPP was created to accommodate public participation in elections. Cadres graduated from SKPP are expected to be an extension of Bawaslu to increase public political participation in the implementation of elections/pilkada.
\end{abstract}

Key Words: SKPP Bawaslu, Participatory Superviso, elections

\section{PENDAHULUAN}

Demokrasi adalah sistem sosial dan politik pemerintahan diri dengan kekuasaan-kekuasaan pemerintah yang dibatasi hukum dan kebiasaan untuk melindungi hak-hak perorangan warga negara (Nurgiansah, 2021a).

Demokrasi merupakan bentuk pemerintahan di mana semua warga negaranya memiliki hak setara dalam pengambilan keputusan. Demokrasi mengizinkan warga negara berpartisipasi baik secara langsung atau melalui perwakilan dalam perumusan, pengembangan, dan pembuatan hukum
(Khoiri \& Irwan, 2020).

Demokrasi merupakan sistem politik yang memberikan ruang bagi keadilan dan persamaan bagi semua warga negara. Sistem ini menjadi pilihan paling populer yang digunakan negara-negara di dunia (Murdiono et al., 2020).

Negara demokrasi mengutamakan kepentingan umum dari pada pribadi, artinya demokrasi merupakan bentuk pemerintahan dimana formulasi kebijakan, secara langsung atau tidak ditentukan oleh suara mayoritas warga yang memiliki hak suara melalui wadah pemilihan (Nurgiansah, 2021b). 
Ciri paling mendasar dari negara demokrasi adalah adanya pemilihan umum (Pemilu), meski pemilu bukanlah satusatunya aspek dalam demokrasi namun pemilu merupakan pilar utama dari sebuah negara demokrasi, karena melalui pemilu rakyat memilih wakilnya yang mana para wakil rakyat ini mendapat mandat kedaulatan rakyat untuk mengurusi negara. Pemilu berperan sebagai mekanisme perubahan politik mengenai pola dan arah kebijakan publik dan/atau mengenai sirkulasi elit secara periodik dan tertib (Nurgiansah, 2020b).

Dalam Pasal 1 UUD 1945 disebutkan bahwa Indonesia merupakan demokrasi, secara etimologis demokrasi terdiri dari dua dari Yunani, yaitu demos yang berarti rakyat atau penduduk suatu tempat dan cratein atau cratos yang berarti kekuasaan atau kedaulatan. Demos- cratein atau demos-cratos (demokrasi) memiliki arti suatu sistem pemerintahan dari, oleh, dan untuk rakyat. Menurut Joseph A. Schmeter, Secara terminologi demokrasi merupakan suatu perencanaan institusional untuk mencapai keputusan politik di mana individu-individu memperoleh kekuasaan untuk memutuskan cara perjuangan kompetitif atas suara rakyat (Dewantara, Hermawan, et al., 2021).

Demokrasi adalah sebuah sistem politik, atau sebuah sistem pengambilan keputusan di dalam suatu lembaga, organisasi, atau negara, yang seluruh anggota atau warganya memiliki jatah kekuasaan yang sama besar. Demokrasidemokrasi modern dicirikan oleh dua keunggulan yang membedakannya secara hakiki dari bentuk-bentuk pemerintahan yang sudah ada sebelumnya, yakni mampu menjadi penengah di dalam lingkup masyarakatnya sendiri, dan diakui kedaulatannya oleh suatu kerangka kerja legalistik dari negara-negara berdaulat yang serupa (Dewantara \& Nurgiansah, 2021).
Sedangkan menurut Henry B. Mayo Demokrasi merupakan sistem yang menunjukkan bahwa kebijakan umum ditentukan atas dasar mayoritas oleh wakil-wakil yang diawasi secara efektif oleh rakyat dalam pemilihana berkala yang didasarkan atas prinsip kesamaan politik dan diselenggarakan dalam suasana terjaminnya kebebasan politik (Dewantara, Nurgiansah, et al., 2021). Rumusan tersebut memberikan sifat pemahaman umum terhadap suatu negara yang menganut sistem demokrasi, yaitu:

a. Demokrasi adalah suatu sistem pemerintahan yang mempunyai elemenelemen yang saling terkait dan tidak dapat dipisahkan.

b. Orang-orang yang memegang kekuasaan atas nama demokrasi dapat mengambil keputusan untuk menetapkan dan menegakkan hukum.

c. Kekuasaan untuk mengatur dalam bentuk aturan hukum tersebut diperoleh dan dipertahankan melalui pemilihan umum yang bebas dan diikuti oleh sebagian besar warga negara dewasa.

Dari penjelasan di atas, dapat diketahui bahwa pengawasan terhadap proses perebutan dan pelaksanaan kekuasaan itu sangatlah penting, sehingga roda pemerintahan dapat berjalan dengan tertib dan lancar. Sistem pengawasan terhadap perebutan kekuasaan harus diperketat untuk menghindari kecurangankecurangan yang dilakukan oleh oknum yang tidak bertanggung jawab (Nurgiansah, 2021d).

Begitu juga dengan Indonesia, Pemilu dilaksanakan sebagai wujud dari demokrasi yang merupakan sarana dalam mengagregasi aspirasi yang ada di masyarakat yang sebelumnya diartikulasikan oleh partai politik sesuai dengan fungsinya.

Pemilu nasional pertama di Indonesia 
diselenggarakan setelah 10 tahun proklamasi kemerdekaan, yaitu tahun 1955. Pemilu pertama ini berlangsung di era pemerintahan Presiden Soekarno. Sebenarnya, pemilu pertama rencananya digelar pada tahun 1946 namun hal tersebut batal dilaksanakan karena beberapa alasan. Tahapan pelaksanaan pemilu 1955 dimulai dengan memilih anggota DPR pada 29 September 1955. Kemudian memilih anggota Dewan Konstituante pada 15 Desember 1955 (Nurgiansah, 2021c).

Selanjutnya, pada tahun 1971 pemilu kedua dilaksanakan pada pemerintahan Soeharto atau disebut juga pemerintahan Orde Baru. Selama 1971-1997 telah terjadi enam kali penyelenggaraan pemilu untuk memilih anggota DPR, DPRD Tingkat I dan DPRD Tingkat II. Menganut sistem perwakilan berimbang (proporsional) dengan sistem stelsel daftar. Pemilu 19711977 menganut asas Langsung, Umum, Bebas dan Rahasia atau dikenal dengan sebutan LUBER (Nurgiansah, 2020a).

Pemilu tahun 1999 merupakan pemilu pertama pada masa reformasi yang menggunakan sistem perwakilan berimbang (proprsional) dengan stelsel daftar dan asas Langsung, Umum, Bebas, Rahasia, Jujur dan Adil alias LUBER JURDIL. Pemilu tahun 1999 dilaksankan pada 7 Juni 1999 bertepatan dengan 13 bulan masa kekuasan BJ Habibie. Pada pemilu tahun 1999 ini diikuti sebanyak 48 partai politik denganjumlah pemilih mencapai 105.786.661 suara.

Pemilu tahun 2004 adalah pemilihan umum pertama pasca amandemen UndangUndang Dasar 1945. Terdapat tiga perubahan pada pemilu tahun 2004, yakni Presiden dipilih secara langsung, kedua dibentuknya Dewan Perwakilan Daerah (DPD). Ketiga, penyelenggaraan pemilu yang nasional, tetap, dan mandiri. Ada dua macam pemilu di tahun 2004, yakni Pemilu Legislatif (DPR, DPD, DPRD) yang diikuti sebanyak 24 partai politik dan dilaksanakan pada 5 April 2004. Kemudian pemilu Presiden dan Wakil Presiden, diikuti 5 pasangan calon dan dilaksanakan sebanyak dua putaran. Putaran pertama pada 5 Juli 2004 dan putaran II pada 20 September 2004.

Pemilu 2009 adalah pemilu ketiga pada masa reformasi yang diselenggarakan secara serentak dengan sistem perwakilan berimbang dan sistem daftar calon terbuka. Pada 9 April dilaksanakan untuk memilih DPR, DPD dan DPRD. Kemudian pada 8 April 2009 dilaksanakan pemilu untuk memilih Presiden dan Wakil Presiden. Pemilihan Umum (Pemilu) tahun 2014 merupakan pemilu ke-11 yang diselenggarakan pada masa reformasi. Pemilu 2014 dilaksanakan dua kali yaitu pada 9 April 2014 untuk memilih anggota legislatif (DPR, DPD, DPRD) dan 9 Juli 2014 untuk memilih presiden dan wakil presiden. Pemilu ini diikuti oleh 10 partai politik. Sistem pemilu proporsional dengan daftar calon terbuka sementara untuk pengambilan suara dilakukan dengan mencoblos satu kali pada nomor/gambar (Nurgiansah, 2019).

Seiring berjalannya waktu, semakin berkembang pulalah kebutuhan pemilu dari waktu ke waktu salah satunya kebutuhan akan pengawas pemilu. Badan Pengawas Pemilu (Bawaslu) dibentuk berdasarkan perintah Undang-Undang no 22 Tahun 2007 tentang Penyelenggara Pemilu. Sebelumnya, Pengawas Pemilu merupakan lembaga adhoc yaitu Panitia Pengawas Pemilu atau Panwaslu. Tepatnya tahun 1982 uu memerintahkan pembentukan Panitia Pengawas Pelaksanaan Pemilu atau Panwaslak Pemilu, yang melekat pada Lembaga Pemilihan Umum atau LPU. Baru pada tahun 2003, Panwaslu dilepaskan dari struktur Komisi Pemilihan Umum atau KPU.

Lembaga Pengawas Pemilu dibentuk 
untuk mengawasi seluruh tahapan penyeleggaraan Pemilu, menerima pengaduan, serta menangani kasus- kasus pelanggaran administrasi Pemilu serta pelanggaran pidana Pemilu berdasarkan tingkatan masing-masing sesuai dengan ketentuan peraturan Perundangundangan. Sebagai lembaga Ad hoc yang dibentuk sebelum tahapan pertama Pemilu dimulai dan dibubarkan setelah calon yang terpilih dalam Pemilu/Pilkada dilantik.

Dengan terbitnya Undang-undang Nomor 7 Tahun 2017 tentang Pemilu, menguatkan kelembagaan ini dengan mengharuskan Pembentukan

Bawaslu Kabupaten/Kota Permanen paling lambat setahun sejak tanggal disahkan Undang-undang ini pada 16 Agustus 2017, ditambah dengan kewenangan baru untuk menindak serta memutuskan pelanggaran dan proses sengketa Pemilu.

\section{Bawaslu RI mengeluarkan}

Perbawaslu Nomor 19 tahun 2017 beserta perubahannya Perbawaslu Nomor 10 Tahun 2018, untuk menugaskan kepada Bawsalu Provinsi untuk mengusulkan dan membentuk Tim Seleksi Anggota Bawaslu Kabupaten/Kota dimasingmasing wilayah kerjanya yang terbagi lagi dari beberapa region serta ditetapkan dengan Keputusan Bawaslu Provinsi masing-masing.

Sebagai lembaga pengawas, Bawaslu tidak bisa menjalankan tugasnya secara optimal apabila hanya berjalan sendirian, untuk mengawasi seluruh tahapan pamilu Bawaslu memerlukan peran serta masyarakat dalam mengawasi proses pemilu sebagai pengawas partisipatif. Salah satu upaya Bawaslu melibatkan masyarakat untuk turut mengawasi pemilu adalah dengan memberikan Pendidikan politik kepada masyarakat umum salah satunya dengan mengadakan Sekolah Kader Pengawas Partisipatif (SKPP).

\section{METODE PENELITIAN}

Penelitian ini menggunakan metode kualitatif berdasarkan studi literatur, yaitu dengan mengumpulkan data berbagai sumber yang berkaitan dengan pembahasan. Setelah mengumpulkan data sumber literatur berkaitan kemudian dilanjutkan dengan menganalisis penelitian ini.

Hal pertama yang dilakukan adalah pengumpulan data dan menjelaskan secara rinci apa saja yang ditemukan, kemudian digabungkan seluruh hasil yang di dapatkan untuk kemudian dilakukan analisis pada seluruh data yang di dapatkan untuk kemudian ditarik kesimpulan.

\section{HASIL PENELITIAN DAN PEMBAHASAN Hasil Penelitian Kondisi Pemilu Indonesia}

Indonesia merupakan salah satu negara yang menganut sistem demokrasi. Sistem pemerintahannya diselenggarakan dari rakyat, oleh rakyat, dan untuk rakyat. Demokrasi do Indonesia tercermin dari diselenggaranya pemilihan umum atau pemilu. Salah satu fungsi pemilu adalah sebagai sarana yang sah bagi warga negara untuk mempertahankan atau mengganti secara damai dan bermartabat pemimpin/wakilnya untuk menjalankan pemerintahan dan memberikan kesempatan bagi warga negara terbaik untuk memimpin masyarakat dalam mewujudkan cita- cita bersama.

Tetapi dalam kenyataannya di Indonesia pemilu seakan menjadi sarana "pertandingan" untuk merebut atau mempertahankan kekuasaan secara alami dan terdapat kecenderungan peserta pemilu di Indonesia bertindak curang. Kecurangan tidak hanya dalam bentuk janji-janji kampanye yang berlebihan, melainkan juga dalam berbagai perbuatan yang nyata-nyata dapat secara langsung mempengaruhi hasil Pemilu seperti Money politik dan Penggelembungan suara/jual- 
beli suara.

Badan Pengawas Pemilu (Bawaslu) RI mencatat terdapat 16.043 temuan dan laporan dugaan pelanggaran di Pemilu 2019. Data tersebut berdasar temuan Bawaslu dan laporan yang diterima lembaga pengawas. Dengan rincian 533 kasus adalah pelanggaran pidana, 1.096 pelanggaran hukum, 162 pelanggaran kode etik, dan 12.138 pelanggaran administrasi dan 980 lainnya bukan termasuk kategori pelanggaran aturan pemilu. Dari angka itu, sebanyak 14.462 dugaan pelanggaran aturan pemilu merupakan temuan pengawas di lapangan. Sementara 1.581 dugaan pelanggaran merupakan laporan yang diterima Bawaslu.

Sedangkan, pada pemilihan kepala daerah atau Pilkaa serentak tahun 2020 Bawaslu Provinsi Jawa Barat mencatat dengan total 288 perkara penangan pelanggaran Pilkada di Jawa Barat dengan 249 temuan dan 39 laporan dan diKanupaten Karawang ditemukan 94 temuan dan 3 laporan mengenai pelanggaran pada pilkada serentak 2020. Dari data tersebut dapat kita ketahui masih sangat menimnya partisipasi masyarakat dalam proses pengawasan pemilu di Indonesia.

\section{Pembahasan \\ Faktor yang Mempengaruhi Partisipasi Politik}

Angka partisipasi sebenarnya dipengaruhi oleh banyak faktor. Namun secara umum terdapat dua alasan besar yang mempengaruhi pemilih dalam menentukan penggunaan hak pilihnya. Dua faktor tersebut adalah kesadaran politik dan kepercayaan kepada pemerintah (sistem politik). Kesadaran politik dipahami sebagai kesadaran akan hak dan kewajiban sebagai warga negara. Hal ini terkait pengetahuan seseorang tentang lingkungan masyarakat dan politik yang menyangkut minat dan perhatian seseorang tersebut terhadap lingkungan masyarakat dan politik di mana dia tinggal. Sementara kepercayaan kepada pemerintah dipahami sebagai penilaian seseorang terhadap pemerintah. Apakah pemerintah dinilai dapat dipercaya dan dipengaruhi atau tidak.

Berdasarkan kedua kategori di atas, ilmuwan politik Jeffry Paige, seperti yang dikutip Surbakti (1992), membaginya menjadi empat kategori. Pertama, jika seorang warga negara memiliki kesadaran politik dan kepercayaan kepada pemerintah yang tinggi, maka partisipasi politik cenderung aktif. Kedua, jika kesadaran politik dan kepercayaan kepada pemerintah rendah, maka partisipasi politik cenderung pasif (apatis). Kategori ketiga adalah militan radikal, yakni apabila kesadaran politik tinggi tetapi kepercayaan kepada pemerintah sangat rendah. Selanjutnya, apabila kesadaran politik sangat rendah, namun kepercayaan kepada pemerintah sangat tinggi, maka partisipasi ini disebut tidak aktif (pasif).

Tentu saja, kesadaran politik dan kepercayaan terhadap pemerintah bukanlah faktor yang berdiri sendiri. Kedua faktor tersebut tetap akan dipengaruhi oleh faktorfaktor lain, seperti status sosial dan status ekonomi, afiliasi politik dan pengalaman berorganisasi. Variabel ini disebut variabel pengaruh atau variabel independen, sementara kesadaran politik dan kepercayaan terhadap pemerintah dikategorikan sebagai variabel antara atau intervening variables. Sementara partisipasi politiksendiri dikategorikan sebagai variabel terpengaruh atau variabel dependen.

\section{Pentingnya Pengawas Partisipatif Dalam Pemilu}

Demokrasi memang bukan satu tatanan yang sempurna untuk mengatur peri kehidupun manusia. Namun sejarah di 
manapun telah membuktikan, bahwa demokrasi sebagai model kehidupan bernegara memiliki peluang paling kecil dalam menistakan kemanusiaan. Oleh karena itu, meskipun dalam berbagai dokumentasi negara ini tidak banyak ditemukan kata demokrasi, para pendiri negara sejak zaman pergerakan berusaha keras menerapkan prinsip-prinsip negara demokrasi bagi Indonesia.

Tiada negara demokrasi tanpa pemilihan umum (pemilu), sebab pemilu merupakan instrumen pokok dalam menerapkan prinsip-prinsip demokrasi. Sesungguhnya, pemilu tidak saja sebagai arena untuk mengekspresikan kebebasan rakyat dalam memilih pemimpinnya, tetapi juga arena untuk menilai dan menghukum para pemimpin yang tampil di hadapan rakyat. Namun, pengalaman di berbagai tempat dan negara menunjukkan bahwa pelaksanaan pemilu seringkali hanya berupa kegiatan prosedural politik belaka, sehingga proses dan hasilnya menyimpang dari tujuan pemilu sekaligus mencederai nilai-nilai demokrasi.

Kenyataan tersebut mengharuskan dilakukannya usaha yang tak henti untuk membangun dan memperbaiki sistem pemilu yang fair, yakni pemilu yang mampu menampung kebebasan rakyat dan menjaga kedaulatan rakyat. Para penyelenggara pemilu dituntut memahami filosofi pemilu, memiliki pengetahuan dan ketrampilan teknis penyelenggaraan pemilu, serta konsisten menjalankan peraturan pemilu, agar proses pemilu berjalan sesuai dengan tujuannya. Selanjutnya, hasil pemilu, yakni para pemimpin yang terpilih, perlu didorong dan diberdayakan terus- menerus agar dapat menjalankan fungsinya secara maksimal; mereka juga perlu dikontrol agar tidak meyalahgunakan kedaulatan rakyat yang diberikan kepadanya.

Sebagaimana diketahui, penyelenggara pemilu di Indonesia terdiri dari Komisi Pemilihan Umum (KPU), Badan Pengawas Pemilu (Bawaslu) dan Dewan Kehormatan Penyelenggra Pemilu (DKPP). Ketiga lembaga inilah yang menerjemahkan undang-undang dan melaksanakannya dengan asas asas berkeadilan dan setara. KPU sebagai pelaksanaan pemilihan umum tentu mendapat porsi perhatian yang lebih besar dalam pengawasan. Akan banyak pihak yang berkepentingan untuk menjadikan KPU dan Bawaslu sebagai koasi kekuasaannya. Dari sinilah diperlukannya pengawalan pada setiap tahapan penyelenggaraan.

Adapun mekanisme pengawasan pemilu tertuang dalam peraturan bersama KPU, Bawaslu dan DKPP Nomor 13 Tahun 2012, Nomor 11 Tahun 2012 dan Nomor 1 Tahun 2012 tentang "Kode Etik Penyelenggara Pemilu”. Peraturan ini menjadi dasar bagi masyarakat untuk membantu mengawal proses pemilihan umum dengan penuh tanggung jawabnya dan berkeadilan.

Menurut Kamus Bahasa Indonesia, arti kata "kawal" yaitu penjagaan. Mengawal artinya menjaga; mengiring untuk menjaga keselamatan. Secara terminologi mengawal pemilu berarti bagaimana menjaga proses pelaksanaan pemilu berjalan dengan aman dan selamat sehingga tercapai tujuan dan cita-cita dari negara yang berdemokrasi. Adapun pihak yang dijaga adalah para penyelenggara pemilu yaitu pihak KPU, Bawaslu, DKPP, Partai Politik serta aparat penegak hukum yang tergabung dalam Gakumdu, Gabungan Penegak Hukum Terpadu. Sedangkan sebagai penjaga adalah sistem masyarakat yang telah terbentuk sejak dari pembentukan bangsa ini yaitu Civil Society yang telah menjadi penggerak perjuangan pembebasan bangsa ini dari penjajahan.

Salah satu Civil Society yang dapat mengawal proses pemilihan oleh penyelenggara pemilu adalah lembaga 
pemantau pemilu. Pelaksanaan pemantau pemilu pada hakikatnya bermakna penglihatan atau melihat sebagian yang bisa kita lihat. Kegiatan ini pada umumnya bisa dilakukan kapan saja, dari mana saja dan dari kelompok masyarakat mana saja. Unsur-unsur masyarakat yang bisa terlibat dalam pemantauan dan pengawasan di antaranya adalah pemilih, peserta pemilu, lembaga pemantau pemilu, media massa, lembaga swadaya masyarakat, dan organisasi kemasyarakatan. UndangUndang Pemilu menyatakan tiga pihak yang dapat menyampaikan laporan tentang penyimpangan pemilu, yaitu pemilih, lembaga pemantau pemilu, dan peserta pemilu.

\section{Sekolah Kader Pengawas Partisipatif (SKPP)}

Badan Pengawas Pemilihan Umum (Bawaslu) adalah lembaga penyelenggara Pemilu yang bertugas mengawasi penyelenggaraan Pemilu di seluruh wilayah Negara Kesatuan Republik Indonesia. Bawalu sebagai Lembaga penyelenggara Pemilu mempunyai keterbatasan dalam mengawasi seluruh tahapan pemilu atau pilkada, maka dari itu Bawaslu membuat beberapa program unggulan untuk meningkatkan partisipasi masyarakat dalam pengawasan pemilu yakni diantaranya Gowaslu, Pengelolaan Media Sosial, Forum Warga Pengawasan Pemilu, Gerakan Sejuta Relawan Pengawas Pemilu, Satuan Karya Pramuka (Saka) Adhyasta Pemilu, Kuliah Kerja Nyata (KKN) Tematik Pengawasan Penyelenggaraan Pemilu, Pojok Pengawasan, dan Sekolah Kader Pengawas Partisipatif.

Sekolah Kader Pengawas Partisipatif (SKPP) adalah sebuah sarana Pendidikan yang disediakan oleh Badan Pengawas Pemilu (BAWASLU) untuk memfasilitasi masyarakat umum agar dapat terlibat dalam mengawasi penyelenggaraan pemilu atau pilkada. SKPP adalah gerakan bersama antara Bawaslu dengan masyarakat untuk menciptakan proses Pemilu yang berintegritas, disatu sisi Bawaslu menyediakan layanan Pendidikan dan disisi lain masyarakat pemilih berinisiatif untuk turut berpartisipasi dalam mengawasi penyelenggaraan Pemilu atau Pilkada.

Pada tahun 2020 dunia dilanda Pandemi COVID-19 yang mengharuskan penerapan pembatasan sosial dan jaga jarak akan tetapi hal itu tidak membuat Bawaslu berhenti melakukan upaya-upaya pendidikan pemilih dan pencegahan pelanggaran pilkada. Bawaslu tetap menggelar Sekolah Kader Pengawas Partisipatif secara daring (SKPP Daring). Program tersebut diselenggarakan mulai Mei 2020.

Lulusan SKPP Daring diharapkan mampu meningkatkan pengetahuan dan keterampilan praktis tentang pengawasan bagi kader-kader pengawas dan pemantau pemilu serta sarana berbagi pengetahuan dan keterampilan tentang partisipasi masyarakat. Dengan menggunakan teknologi informasi dan media sosial, SKPP Daring menjadi jalan keluar dari keterbatasan ruang dan waktu dalam penguatan partisipasi masyarakat dalam pengawasan pemilu dan pilkada.

SKPP Daring adalah sarana pendidikan pemilu dan pilkada serta pengawasannya bagi masyarakat. Melalui SKPP Daring, Bawaslu berupaya menyediakan fasilitas yang baik dan optimal bagi masyarakat untuk memperoleh pengetahuan dan keterampilan melakukan pengawasan partisipatif.

Tujuan penyelenggaraan SKPP Daring adalah untuk meningkatkan pengawasan partisipatif pemilu dan pilkada oleh masyarakat. Pengawasan partisipatif tersebut merupakan hasil dari semakin banyak pihak yang mengetahui tugas, pokok dan fungsi pengawasan pemilu dan pilkada. 
Selain sebagai pengawas partisipatif, peserta SKPP Daring nantinya akan menjadi kader yang merupakan perpanjangan tangan Bawaslu dalam menggerakkan masyarakat untuk turut melakukan pengawasan partisipatif pemilu dan pilkada. SKPP daring ini dilakukan oleh masing-masing Bawaslu Kabupaten/Kota. Output dari SKPP daring ini ialah para lulusan menjadi kader pengawas partisipatif Kabupaten/kota-nya. Tidak hanya berhenti sampai disitu, Bawaslu tingkat provinsi memanggil 3 orang lulusan terbaik dari setiap Kabupaten/Kota untuk mengikuti SKPP luar jaringan (secara langsung) untuk lebih menambah pengetahuan lagi mengenai pengawasan pemilu/pilkada.

\section{KESIMPULAN}

Dengan semakin berkmbangnya zaman, semakin berkembang pulalah aneka kerawanan dan pelanggaran dalam pemilu, bukan hanya pelanggaran dan kerawanan tapi partisipasi politik dalam pemilu yang terus menurun dari pemilu pertama hingga sekarang menunjukan bahwa pemberian Pendidikan politik khususnya tentang kepemiluan sangat diperlukan saat ini.

Sekolah Kader Pengawas Partisipatif (SKPP) yang diselenggarakan oleh Badan Pengawas Pemilu (Bawaslu) dapat menjadi salah satu upaya yang dilakukan untuk memberikan Pendidikan politik kepada masyarakat umum yang nantinya diharapkan dapat meningkatkan partisipasi politik warga negara.

\section{DAFTAR PUSTAKA}

A. D, W. (2019). Teori teori demokrasi. http://repository.unpas.ac.id/, 16.

Agus. (2021, juni 22). SEJARAH

BAWASLU. Retrieved from Web Site Bawaslu Jakarta Timur diakses pada: https://jakartatimur.bawaslu.g o.id/sejarah-bawaslu/

Budiardjo, M. (1985). Demokrasi di Indonesia (Kumpulan Karangan). Jakarta: Gramedia.

Dewantara, J. A., Hermawan, Y., Yunus, D., Prasetiyo, W. H., Efriani, Arifiyanti, F., \& Nurgiansah, T. H. (2021). Anti-Corruption Education as an Effort to Form Students With Character Humanist and Law-Compliant. Jurnal Civics: Media Kajian Kewarganegaraan, 18(1), 7081.

Dewantara, J. A., \& Nurgiansah, T. H. (2021). Building Tolerance Attitudes Of PPKN Students Through Multicultural Education Courses. Jurnal Etika Demokrasi, 6(1), 103-115.

Dewantara, J. A., Nurgiansah, T. H., \& Rachman, F. (2021). Mengatasi Pelanggaran Hak Asasi

Manusia dengan Model Sekolah Ramah HAM (SR-HAM). Edukatif: Jurnal Ilmu Pendidikan, 3(2), 261-269.

H. B, M. (1960). An Introduction to Democratic Theory. New York: Oxford Univercity Pers. Huntington, S. P. (2010). Partisipasi Politik di Negara Berkembang. Jakarta: Rineka Cipta.

Khoiri, M., \& Irwan, I. (2020). Nasionalisme Masyarakat di Perbatasan Indonesia-Singapura:

Studi Kasus Masyarakat Tionghoa-Batam. Journal of Moral and Civic Education, 4(1), 1118. https://doi.org/10.24036/8851412412020232

Murdiono, M., Suyato, S., \& Arpannudin, I. (2020). Strategi Penguatan Nasionalisme

Perbatasan Indonesia. Jurnal Pancasila Dan Kewarganegaraan, 5(2), 34-43. https://doi.org/10.24269/jpk.v5.n2.2020.pp34-43

Nurgiansah, T. H. (2019). Pemutakhiran Kurikulum Pendidikan Kewarganegaraan di Era Revolusi Industri 4.0. Prosiding Seminar Kewarganegaraan Universitas Negeri Medan, 1(1), 95-102.

Nurgiansah, T. H. (2020a). Fenomena Prostitusi Online Di Kota Yogyakarta Dalam Persfektif 
Nilai Kemanusiaan Yang Adil Dan Beradab. Jurnal Kewarganegaraan, 17(1), 27-34. https://doi.org/10.24114/jk.v17i1.14208

Nurgiansah, T. H. (2020b). Filsafat Pendidikan. In Banyumas: CV Pena Persada.

Nurgiansah, T. H. (2021a). Partisipasi Politik Masyarakat Sleman di Masa Pandemi Covid-19 dalam Konteks Pendidikan Kewarganegaraan. Jurnal Civic Hukum, 6(1), 1-9.

Nurgiansah, T. H. (2021b). Pendidikan Pancasila. In Solok: CV Mitra Cendekia Media.

Nurgiansah, T. H. (2021c). Petuah Pendidikan Kewarganegaraan Dalam Kontestasi Politik. AoEJ: Academy of Education Journal, 12(1), 39-47.

Nurgiansah, T. H. (2021d). The Role of Citizenship Education in Building Bantul Community Political Participation in The Pandemic Covid 19. Prosiding Seminar Nasional Pendidikan Dan Kewirausahaan, 4(1), 1-4.

Nurmalia, M. (2021, Juni 22). Sejarah Singkat Perjalanan Pemilu di Indonesia. Retrieved from Berita baik.id diakses pada: https://beritabaik.id/read?edit orialSlug=indonesiabaik\&slug=1554014910545- sejarah-singkat-perjalanan- $\quad$ pemilihan-umum-diindonesia

Ramadhanil Fadli. (2015). Desain Partisipasi Mayarakat dalam Pemantauan Pemilu. Jakarta: Kemitraan bagi Pembaruan Tata Pemerintahan di Indonesia.

Ratnia, Solihah. (2018). PENTINGNYA PENGAWASAN PARTISIPATIF DALAM MENGAWAL PEMILIHAN UMUM YANG DEMOKRATIS. Jurnal Wacana Politik - Vol. 3, No. 1, 14 - 28.

Sanit, A. (2016). Perwakilan Politik Indonesia. Jakarta: CV Rajawali.

Septiano, B. (2019). Bawaslu Catat Ada 16.043 Laporan dan Temuan Pelanggaran Pemilu. Jakarta: Trito.id.

Surbakti. (1992). Memahami Ilmu Politik. Jakarta: Grasindo.

Surbakti, R. (2008). Perekayasaan Sistem Pemilihan Umum untuk Membangun Tata Politik Demokratis. Jakarta: Kemitraan Bagi Tata Pemerintahan di Indonesia.

Wahyudi. (2021, Juni 23). URGENSI PENGAWASAN PARTISIPATIF UNTUK MEWUJUDKAN PEMILU YANG DEMOKRATIS. Retrieved from Bawaslu Grobongan: grobogan.bawaslu.ac.id 